\title{
Modulation of Calcium Currents by a Metabotropic Glutamate Receptor Involves Fast and Slow Kinetic Components in Cultured Hippocampal Neurons
}

\author{
Yoshinori Sahara' ${ }^{1}$ and Gary L. Westbrook ${ }^{1,2}$ \\ ${ }^{1}$ Vollum Institute and ${ }^{2}$ Department of Neurology, Oregon Health Sciences University, Portland, Oregon 97201
}

The modulation of high-threshold $\mathrm{Ca}^{2+}$ currents by the selective metabotropic glutamate receptor (mGluR) agonist (1S,3R)-1-aminocyclopentane-1,3-dicarboxylic acid (ACPD), was investigated in cultured hippocampal neurons using whole-cell voltage-clamp recording. ACPD reduced highthreshold $\mathrm{Ca}^{2+}$ currents carried by $\mathrm{Ba}^{2+}$ with an $\mathrm{EC}_{50}$ of 15.5 $\mu \mathrm{M}$. The inhibition was reversible, voltage dependent, and blocked by L-2-amino-3-phosphonopropionic acid (1 $\mathrm{mm}$ ) or by pretreatment with pertussis toxin. Inhibition by ACPD was greatly enhanced, and became irreversible, when the nonhydrolyzable GTP analog GTP $\gamma \mathbf{S}$ was included in the wholecell pipette. In some neurons, the $\mathrm{Ba}^{2+}$ current was inhibited by $L(+)$-2-amino-4-phosphonobutanoic acid (L-AP4) as well as ACPD while most cells were insensitive to L-AP4, suggesting that these agonists activate distinct receptors. The inhibition of $\mathrm{Ca}^{2+}$ currents was reduced but not eliminated in the presence of either $\omega$-conotoxin GVIA or nifedipine, suggesting that both $\mathrm{N}$ - and L-type $\mathrm{Ca}^{2+}$ currents were affected. The degree and kinetics of inhibition were dependent on intracellular calcium. With $[\mathrm{Ca}]_{i}<1 \mathrm{nM}$, inhibition had a fast onset ( $t \approx 1-2 \mathrm{sec}$ ) and a rapid recovery, consistent with a membrane-delimited pathway. However, a slow component of inhibition appeared when the steady state [Ca] was increased to $100 \mathrm{~nm}$ ( $t$ onset $\approx 3 \mathrm{~min}$ ). The slow component did not require transient $\mathrm{Ca}^{2+}$ influx or release of intracellular $\mathrm{Ca}^{2+}$. We suggest that $\mathrm{Ca}^{2+}$ channel modulation by $A C P D$ involves either two mGluR subtypes with separate coupling mechanisms or a single mGluR that couples to both mechanisms.

[Key words: metabotropic glutamate receptors, calcium channels, G-proteins, L-2-amino-4-phosphonobutanoic acid, hippocampus, trans-ACPD]

Glutamate activates two types of receptors, ligand-gated ion channels and G-protein-coupled (metabotropic) receptors (mGluRs). The ligand-gated ion channels have well established roles in excitatory synaptic transmission (for review, see Mayer and Westbrook, 1987; Collingridge and Lester, 1989), but the

Received Oct. 15, 1992; revised Jan. 21, 1993; accepted Feb. 25, 1993.

We thank J. Volk for preparation of cell cultures and Dr. Bruce Bean for a preprint of a manuscript in press. This work was supported by grants from the National Institutes of Health (NS26494) and the Klingenstein Fund for the Neurosciences.

Correspondence should be addressed to Gary L. Westbrook, Vollum Institute, L-474, Oregon Health Sciences University, 3181 S.W. Sam Jackson Park Road, Portland, OR 97201.

Copyright (c) 1993 Society for Neuroscience $0270-6474 / 93 / 133041-10 \$ 05.00 / 0$ physiological functions of mGluRs are much less defined (Schoepp et al., 1990a). mGluRs were first identified in mRNAinjected Xenopus oocytes as coupled to inositol phospholipid metabolism (Sugiyama et al., 1987). Recently, five mGluRs have been cloned that have several intracellular transduction mechanisms and distinctive expression patterns (Houamed et al., 1991; Masu et al., 1991; Abe et al., 1992; Tanabe et al., 1992).

Pharmacological and physiological studies have just begun to characterize mGluRs, although this has been hampered by a lack of high-affinity ligands or effective antagonists. One major action of mGluRs in hippocampal neurons appears to be modulation of potassium and calcium channels (Charpak et al., 1990; Lester and Jahr, 1990; Desai and Conn, 1991). In addition, L-2amino-4-phosphonobutanoic acid (L-AP4), a glutamate analog that does not activate mGluR1 (Houamed et al., 1991), inhibits synaptic transmission and voltage-sensitive $\mathrm{Ca}^{2+}$ currents in cultured olfactory bulb neurons via a G-protein-coupled receptor (Trombley and Westbrook, 1992). Thus, more than one $G$-protein-coupled glutamate receptor may be involved in modulation of $\mathrm{Ca}^{2+}$ channels.

It has been proposed that modulation of $\mathrm{Ca}^{2+}$ channels by glutamate or L-AP4 is membrane delimited (Lester and Jahr, 1990; Trombley and Westbrook, 1992). However, the existence of multiple mGluR subtypes and the activation of three diffusible second messengers even by a single mGluR receptor (Aramori and Nakanishi, 1992) provide multiple possible coupling mechanisms. The best-studied biochemical action of mGluR activation in hippocampal neurons is inositol trisphosphate ( $\left.\operatorname{IP}_{3}\right)$ production and mobilization of $\mathrm{Ca}^{2+}$ from intracellular stores (Murphy and Miller, 1988; Furuya et al., 1989; Schoepp et al., 1990a).

The $\mathrm{Ca}^{2+}$ channel subtypes that are modulated by mGluRs are also unclear. Although $\mathrm{N}$-type channels, the predominant $\mathrm{Ca}^{2+}$ channel subtype in neurons of the PNS, are a major target of neurotransmitter modulation (for revicw, scc Tsien et al., 1988; Hess, 1990), in hippocampal neurons, N-, L-, and P-type $\mathrm{Ca}^{2+}$ channels contribute approximately equally to the wholecell current (Regan et al., 1991; Mintz et al., 1992). In acutely dissociated cortical neurons, L-type channels were inhibited by an mGluR (Sayer et al., 1992) whereas N-type channels were inhibited in acutely dissociated CA3 neurons (Swartz and Bean, 1992a).

In order to elucidate the mechanisms of the $\mathrm{Ca}^{2+}$ channel modulation by mGluRs, we focused on three issues: (1) whether (1S,3R)-1-aminocyclopentane-1,3-dicarboxylic acid (ACPD) and L-AP4 mediated inhibition of $\mathrm{Ca}^{2+}$ channels involves distinct receptors, (2) whether $\mathrm{Ca}^{2+}$ channel modulation by ACPD is 
dependent on $\left[\mathrm{Ca}^{2+}\right]_{i}$, and (3) which $\mathrm{Ca}^{2+}$ channel subtypes are affected. Our results suggest that ACPD and $\mathrm{L}-\mathrm{AP} 4$ act via separate receptors to reduce voltage-dependent $\mathrm{Ca}^{2+}$ currents in cultured hippocampal neurons. The action of ACPD involves fast and slow kinetic components resulting in a decrease in both $\mathrm{N}$ - and L-type $\mathrm{Ca}^{2+}$ channel activity.

A preliminary report has appeared in abstract form (Sahara and Westbrook, 1991).

\section{Materials and Methods}

Cell culture. Primary cultures of rat hippocampal neurons were prepared from neonatal rat pups (Sprague-Dawley). Pups were anesthetized with halothane and decapitated, and the hippocampi removed and cut into $1 \mathrm{~mm}$ slices. The slices were incubated in activated papain $(20 \mathrm{U} / \mathrm{ml}$, 45-60 $\mathrm{min})$, dissociated by gentle trituration, and plated ( 10,000 cells/ $\mathrm{cm}^{2}$ ) on a confluent layer of hippocampal astrocytes as previously described (Legendre and Westbrook, 1990). The culture medium contained Minimum Essential Medium (GIBCO), $0.6 \%$ glucose, $5 \%$ heatinactivated horse serum (Hyclone), and a supplement including $200 \mu \mathrm{g} /$ $\mathrm{ml}$ transferrin, $200 \mu \mathrm{M}$ putrescine, $60 \mathrm{nM}$ sodium selenite, $40 \mathrm{nM}$ progesterone, $40 \mathrm{ng} / \mathrm{ml}$ corticosterone, $20 \mathrm{ng} / \mathrm{ml}$ triiodothyronine, and 10 $\mu \mathrm{g} / \mathrm{ml}$ insulin. Half of the medium was changed twice weekly.

Electrophysiology. Currents were recorded in the whole-cell patchclamp mode using a patch-clamp aniplifier (PC-501, Warner Instrument Co., Hamden, CT). Recordings were made from well-isolated pyramidal-shaped neurons after $5-7 \mathrm{~d}$ in culture. All experiments were done at room temperature. The extracellular recording solution contained (in mм) $165 \mathrm{NaCl}, 2.5 \mathrm{KCl}, 2.5 \mathrm{BaCl}_{2}, 1 \mathrm{MgCl}_{2}, 10 \mathrm{~N}$-[2-hydroxyethyl] piperazine- $N^{\prime}$-[2-ethanesulfonic acid] (HEPES), and 10 glucose; $\mathrm{pH}$ was adjusted to 7.3 with $\mathrm{NaOH}$ and osmolarity to $325 \mathrm{mOsm}$. Tetrodotoxin (TTX; $1 \mu \mathrm{M}$ ) and tetraethylammonium chloride ( $5 \mathrm{mM}$ ) were added to block voltage-dependent sodium channels and potassium channels; strychnine $(2 \mu \mathrm{M})$, picrotoxin $(50 \mu \mathrm{M})$, and 7-chlorokynurenic acid ( 500 nM) were added to block glycine, $\gamma$-aminobutyric acid, and $N$-methyl$D$-aspartate (NMDA) channel activity. The chamber was continuously perfused at $1 \mathrm{ml} / \mathrm{min}$ with extracellular solutions in which $\mathrm{Ca}^{2+}$ was substituted for $\mathrm{Ba}^{2+}$. This prevented $\mathrm{Ba}^{2+}$-induced depolarization of other neurons in the culture with subsequent increases in synaptic activity.

Patch pipettes were fabricated from thin-wall borosilicate glass (1.5 mm o.d.; WPI Inc., Sarasota, FL), coated with Sylgard (Dow-Corning Corp., MI), and fire polished, and had DC resistances of 2-5 M . Recordings pipettes contained $160 \mathrm{~mm}$ cesium methanesulfonic acid (Aldrich Chemical Co. Inc., WI), $10 \mathrm{~mm}$ HEPES, $11 \mathrm{~mm}$ ethyleneglycolbis-( $\beta$-aminoethyl ether)- $N, N, N^{\prime}, N^{\prime}$-tetra-acetic acid (EGTA), $5 \mathrm{~mm}$ $\mathrm{MgCl}_{2}, 1 \mathrm{~mm} \mathrm{CaCl}, 5 \mathrm{~mm}$ adenosine 5 -triphosphate (ATP; disodium salt), and 0.5-1 mM guanosine 5'-triphosphate (GTP; sodium salt); $\mathrm{pH}$ was adjusted to 7.3 with $\mathrm{CsOH}$ and osmolarity to 315 mOsm. ATP and GTP were diluted into the intracellular solutions for each experiment and stored on ice until needed. In some experiments, the pipettc $\mathrm{Ca}^{2+}$ concentration was adjusted by substituting $11 \mathrm{~mm}$ bis-( $O$-amino-phenoxy-ethane- $N, N, N^{\prime}, N^{\prime}$-tetra-acetic acid (BAPTA) for EGTA; $\mathrm{Ca}^{2+}$ was added to give the desired buffered $\mathrm{Ca}^{2+}$ concentration based on the BAPTA dissociation constant reported by Tsien (1980). These were 11 mM BAPTA + $0 \mathrm{mM} \mathrm{Ca}^{2+}\left(\left[\mathrm{Ca}^{2+}\right]<10^{9} \mathrm{M}\right), 11 \mathrm{BAPTA}+2.5 \mathrm{Ca}^{2+}$ $\left(\left[\mathrm{Ca}^{2+}\right]=3 \times 10^{-8} \mathrm{M}\right)$, and $11 \mathrm{BAPTA}+5 \mathrm{mM} \mathrm{Ca}^{2+}\left(\left[\mathrm{Ca}^{2+}\right]=10^{-7}\right.$ M).

Drug applications. Drugs were diluted in the $\mathrm{Ba}^{2+}$ control solution and delivered via a linear array of six glass capillary tubes $(400 \mu \mathrm{m}$ diameter) mounted on a micromanipulator, and positioned within $\approx 200$ $\mu \mathrm{m}$ of the cell. Solution flow was controlled with three-way latching solenoid valves. To assess the kinetics of $(1 S, 3 R)$-1 -aminocyclopentane1,3-dicarboxylic acid (ACPD) modulation, solution exchange was performed by simultaneously opening one valve and closing the adjacent valve. This allowed solution exchange within $100 \mathrm{msec}$ (see, e.g., Lester et al., 1990). ACPD and L-2-amino-3-phosphonopropionic acid (L-AP3) were purchased from Tocris Neuramin (Bristol, U.K.); $\mathrm{L}(+)-2$-amino4-phosphonobutanoic acid (L-AP4) and 7-chlorokynurenic acid were from Cambridge Research Biochemical Inc. (Wilmington, DE); guanosine 5'-0-(3-thiotriphosphate) (GTP $\gamma$ S; tetralithium salt), picrotoxin, TTX, DL-2-amino-5-phosphonovaleric acid (DL-AP5), $\omega$-conotoxin $(\omega-$ $\mathrm{CgTx}$ ), and nifedipine from Sigma (St. Louis, MO); and BAPTA from Molecular Probes Inc. (Eugene, OR). Nifedipine and 7-chlorokynurenic acid were dissolved in ethanol and then diluted in water and stored at $-20^{\circ} \mathrm{C}$; the highest final concentrations of ethanol were $0.01 \%$ and $0.002 \%$, respectively. Other drug were dissolved in water. In some experiments, neuronal cultures were incubated at $37^{\circ} \mathrm{C}$ with pertussis toxin (PTX; Sigma, $0.5 \mu \mathrm{g} / \mathrm{ml}$ ) for $24-30 \mathrm{hr}$.

Data acquisition and analysis. Following establishment of whole-cell recording, $5 \mathrm{~min}$ was allowed for equilibration of patch pipette contents with the cytoplasm before the beginning of data collection. During this time the neuron was perfused with the extracellular $\mathrm{Ca}^{2+}$ solution. However, following the initiation of data collection, the neuron was continuously perfused with $\mathrm{Ba}^{2+}$ solution from one of the flowpipes. Depolarizing voltage jumps $(30 \mathrm{msec})$ were delivered at regular intervals (3/ min) under computer control to elicit $\mathrm{Ba}^{2+}$ currents. Current records were corrected for linear leakage and capacitance using a $P / 4$ procedure For kinetic experiments, $10 \mathrm{msec}$ voltage steps from $-60 \mathrm{mV}$ to $0 \mathrm{mV}$ at $1 \mathrm{sec}$ intervals were used, the current remaining in $\mathrm{Cd}^{2+}(100 \mu \mathrm{M})$ was used for leak subtraction. Currents records were low-pass filtered with an 8-pole Bessel filter at $2 \mathrm{kHz}$, digitized at $5 \mathrm{kHz}$, and stored on an IBM-AT using pCLAMP (version 5.5). Data were analyzed on a Macintosh using AXOGRAPH software (Axon Instruments). For display, the initial 500-1000 $\mu \mathrm{sec}$ following a voltage step were blanked to eliminate uncompensated capacitance transients. There were small differences between the time to peak for different neurons; thus, the amplitude of $\mathrm{Ba}^{2+}$ currents was measured by averaging a short data segment $15-20$ msec following onset of the voltage jump; comparison with measurement made at peak current revealed no systematic differences. Currents that showed ohvious changes in the slope of activation, suggesting poor space clamp, were discarded. Although ATP was included in the wholecell pipette, most cells still showed significant current rundown within 1530 mins; thus, to measure current inhibition, the current in the presence of drug was compared to the average of the current amplitude immediately before drug application and following washout. This procedure underestimated the initial inhibition by approximately $10 \%$ in most cells. Data are expressed as mean \pm SD. The significance of the results was determined using Student's $t$ test or, where applicable, paired $t$ test.

\section{Results}

Whole-cell voltage-clamp recordings were made from hippocampal neurons after 5-7 d culture. High-threshold $\mathrm{Ca}^{2+}$ currents were evoked by depolarizing voltage steps from -60 to 0 $\mathrm{mV}$ using $\mathrm{Ba}^{2+}(2.5 \mathrm{~mm})$ as the charge carrier. The inward currents $\left(I_{\mathrm{Ba}}\right)$ had negligible inaclivation during the $30 \mathrm{msec}$ pulse and were completely blocked by $\mathrm{Cd}^{2+}(100 \mu \mathrm{M})$. In some neurons, especially those older than $7 \mathrm{~d}$ in culture, the activation of $I_{\mathrm{Ba}}$ showed evidence of poor space clamp; these neurons were not further analyzed.

\section{$A C P D$ reversibly inhibits high-threshold $\mathrm{Ca}^{2+}$ currents}

To examine mGluR modulation of $I_{\mathrm{Ba}},(1 S, 3 R)$-ACPD, the active stereoisomer of trans-ACPD, was applied by rapid perfusion. ACPD inhibited $I_{\mathrm{Ba}}$ in the majority of neurons tested. Figure $1 A$ shows current traces from immediately before and after application of $200 \mu \mathrm{M}$ ACPD. For neurons dialyzed with $11 \mathrm{~mm}$ EGTA $(\mathrm{pCa}=8)$ and GTP, the reduction of $I_{\mathrm{Ba}}$ was 21.2 $\pm 8.5 \%(n=27)$. As is apparent in Figure $1 A$, the inhibition was gradually relieved during the depolarizing voltage step. The inhibition could not be attributed to NMDA receptor activation (see Chernevskaya et al., 1991), as NMDA receptors were blocked by adding $\mathrm{Mg}^{2+}$ (1 $\mathrm{mm}$ ) and 7-chlorokynurenic acid (500 nM), although on some neurons ACPD produced small inward holding currents $(5-10 \mathrm{pA})$. These were not investigated further. ACPD reduced $I_{\mathrm{Ba}}$ rapidly and was completely reversible following return to the control solution (Fig. $1 B$ ). Although $I_{\mathrm{Ba}}$ ran down despite inclusion of ATP in the pipette, repeated applications of ACPD were still effective. However in most cells the percentage inhibition was largest following the first application and gradually decreased on subsequent exposures to ACPD. For example, the inhibition decreased from $(20.5 \pm 6.1 \%$ to 15.9 

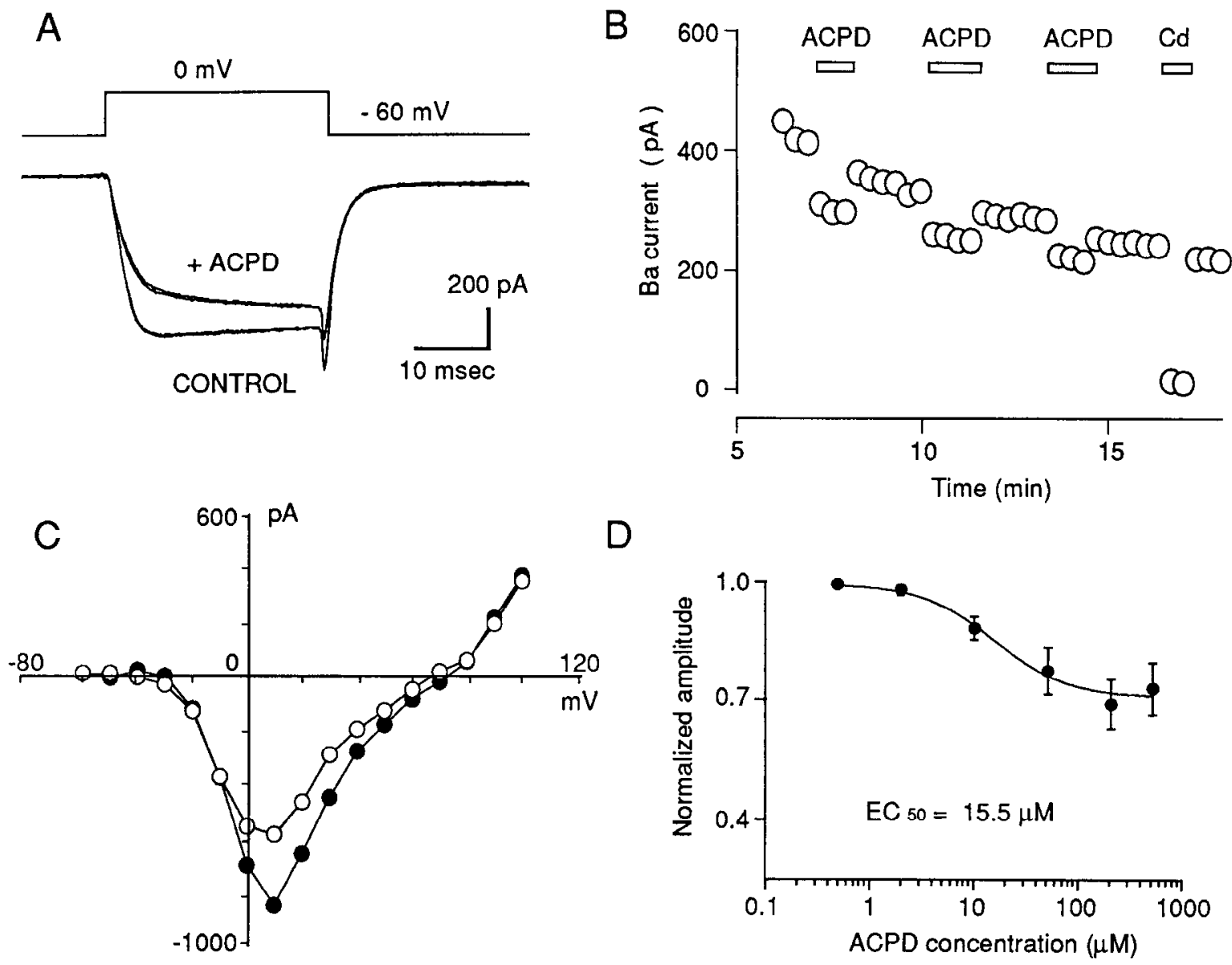

Figure 1. ACPD inhibits high-threshold $\mathrm{Ca}^{2+}$ currents. $A$, Rapid perfusion of ACPD reversibly inhibited high-threshold Ca ${ }^{2+}$ currents, evoked by $30 \mathrm{msec}$ depolarizing pulses from -60 to $0 \mathrm{mV}$. Ba ${ }^{2+}(2.5 \mathrm{~mm})$ was used as the charge carrier. Patch pipettes were buffered to pCa $=8$ with 11 mM EGTA and $1 \mathrm{mM} \mathrm{Ca}^{2+}$. Leak-subtracted currents immediately before and after ACPD application (200 $\mu \mathrm{M}$ ) are superimposed. In the presence of ACPD, a slow relief of inhibition was observed during the voltage step. $B$, Inhibition produced by repeated applications of ACPD gradually declined during $20 \mathrm{~min}$ of whole-cell recording. $I_{\mathrm{Ba}}$ was evoked at $20 \mathrm{sec}$ intervals. $C$, The $I-V$ relationship in Ba ${ }^{2+}$ solution in the absence (solid circles) and presence (open circles) of $200 \mu \mathrm{M}$ ACPD. $I_{\mathrm{Ba}}$ was unaffected at positive holding potentials. $D$, Concentration-response curve for ACPD inhibition of $I_{\mathrm{Ba}}$. The data set includes only neurons tested with at least three agonist concentrations. Data was fitted to the logistic equation $I=$ $1-I_{\max } /\left(1+\left(\mathrm{FC}_{-50} /[\mathrm{ACPD}]\right)^{\mathrm{n}}\right)$, where $I$ is the normalized current amplitude, $I_{\max }$ is the response at saturating [ACPD], EC ${ }_{s o}$ is the [ACPD] that produces $50 \%$ of the maximum response, and $n$ is the slope factor. $I_{\max }$ was 0.38 .

$\pm 4.3 \%$ during three sequential applications of $\operatorname{ACPD}(n=7)$. As not all neurons were ACPD sensitive, subsequent analysis is based on neurons $(n=138)$ that demonstrated $>10 \%$ inhibition. We also occasionally observed small potentiation of $I_{\mathrm{Ba}}$ by ACPD in otherwise typical neurons, but this did not occur with sufficient frequency to allow further analysis.

Figure $1 C$ shows the current-voltage relationship measured in control solution and in the presence of $200 \mu \mathrm{M}$ ACPD. Relief of $I_{\mathrm{Ba}}$ inhibition was observed at positive holding potentials as has been observed for several neurotransmitter receptors (e.g., Bean, 1989; Elmslie et al., 1990). The concentration-response curve for ACPD modulation of $I_{\mathrm{Ba}}(n=6)$ is shown in Figure 1D. ACPD had little effect at $2 \mu \mathrm{M}$ and was maximally effective at $200 \mu \mathrm{M}$. The data were fitted to the logistic equation with an $\mathrm{EC}_{50}=15.5 \mu \mathrm{M}$ and a slope factor $(n)=1.25$. This closely parallels the $\mathrm{EC}_{30}$ reported for activation of mGluRs by transACPD in other preparations (Schoepp et al., 1990a).

\section{A PTX-sensitive G-protein mediates the action of $A C P D$}

PTX has been reported to block L-AP4 modulation of $\mathrm{Ca}^{2+}$ currents (Trombley and Westbrook, 1992), but PTX was ineffective in blocking $\mathrm{mGluR}$ modulation of $\mathrm{Ca}^{2+}$ channels (e.g.,
Lester and Jahr, 1990; Swartz and Bean, 1992a). We first confirmed that $\mathrm{Ca}^{2+}$ channel modulation by ACPD required a G-protein by including the nonhydrolyzable GTP analog GTP $\gamma$ (100-200 $\mu \mathrm{M})$ in the recording pipette. GTP $\gamma \mathrm{S}$ markedly increased the inhibition of $I_{\mathrm{Ba}}$ by ACPD compared to GTP, and as expected the inhibition was irreversible (Fig. $2 A$ ). For GTP $\gamma \mathrm{S}$ the inhibition of $I_{\mathrm{Ba}}$ was $44.8 \pm 12.5 \%(n=5)$ compared to $23.4 \pm 8.7 \% ; n=9 ; P<0.01$ ) for G'IP (Fig. $2 B$ ). Subsequent applications of ACPD produced little or no additional inhibition.

To test the PTX sensitivity of ACPD responses, hippocampal neurons were incubated for $24-30 \mathrm{hr}$ at $37^{\circ} \mathrm{C}$ with PTX $(0.5 \mu \mathrm{g} /$ $\mathrm{ml})$. Following PTX treatment, ACPD (with GTP in the pipette) produced only a $4.1 \pm 2.0 \%(n=5)$ inhibition of $I_{\mathrm{Ba}}$. This was significantly less that inhibition in untreated sister cultures $(21.3$ $\pm 2.6 \% ; n=5 ; P<0.01)$ or in sister cultures treated with heatinactivated PTX $(17.8 \pm 6.3 \% ; n=4)$.

\section{L-AP3 antagonizes $A C P D$}

L-AP3 has been reported to be a noncompetitive antagonist of mGluRs (Schoepp et al., 1990b), but L-AP3 was ineffective in antagonizing mGluR 1 and mGluR5 in CHO cells (Abe et al., 

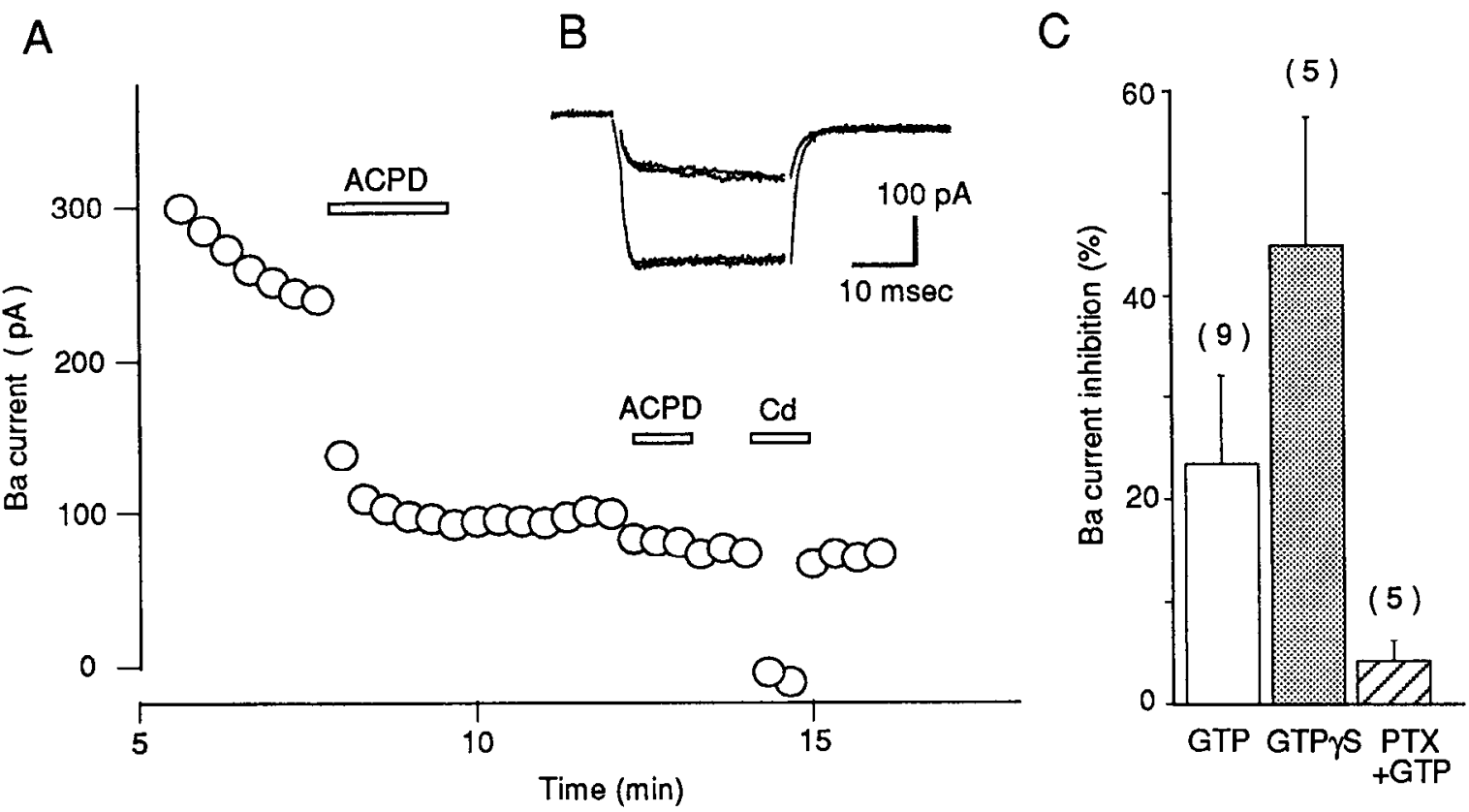

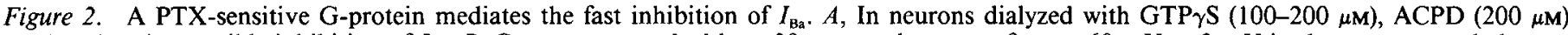
produced an irreversible inhibition of $I_{\mathrm{Ba}} . B$. Current was evoked by a $30 \mathrm{msec}$ voltage step from $-60 \mathrm{mV}$ to $0 \mathrm{mV}$ in the presence and absence of ACPD. Initial $1 \mathrm{msec}$ following the voltage step was blanked. $C$, The reduction in $I_{\mathrm{Ba}}$ was significantly larger in cells dialyzed with GTP $\mathrm{S}$ compared to GTP $(P<0.01)$. However, following preincubation with PTX $\left(0.5 \mu \mathrm{g} / \mathrm{ml}, 24-30 \mathrm{hr}\right.$ at $\left.37^{\circ} \mathrm{C}\right)$, the modulation of $I_{\mathrm{Ba}}$ by ACPD was blocked.

1992; Aramori and Nakanishi, 1992). However, L-AP3 did antagonize ACPD-induced mGluR1 responses in Xenopus oocytes (Houamed et al., 1991) and quisqualate-induced IP 3 synthesis and $\mathrm{Ca}^{2+}$ mobilization in neurons (Irving et al., 1990; Schoepp et al., 1990b). The ability of L-AP3 to block ACPD modulation of $I_{\mathrm{Ba}}$ was examined as shown in Figure 3. At submaximal concentrations of ACPD $(50-100 \mu \mathrm{M}), \mathrm{L}-\mathrm{AP} 3(1 \mathrm{mM})$ blocked $I_{\mathrm{Ba}}$ inhibition (Fig. $3 A, B$ ). For five neurons, inhibition by ACPD was $18.0 \pm 8.8 \%$, and $6.2 \pm 1.8 \%$ in the absence and presence of L-AP3 $(P<0.05$; Fig. $3 C$ ). However, at high concentrations of ACPD $(200 \mu \mathrm{M}), I_{\mathrm{Ba}}$ modulation was completely unaffected by L-AP3 $(n=8)$. This suggests that L-AP3 is a low-affinity competitive $\mathrm{mGluR}$ antagonist. In addition, higher concentrations of L-AP3 ( $1 \mathrm{mM}$ ) directly reduced the amplitude of the $\mathrm{Ca}^{2+}$ current. This was abolished by DL-AP5 (100 $\left.\mu \mathrm{M}\right)$ in combination with $\mathrm{Mg}^{2+}(1 \mathrm{~mm})$ and 7-chlorokynurenic acid (500 $\mathrm{nM}$, consistent with an agonist action of $\mathrm{L}$-AP3 on NMDA receptors.

\section{$L-A P 4$ and $A C P D$ modulate $\mathrm{Ca}^{2+}$ currents via different receptors}

L-AP4 has been reported to activate a G-protein-coupled glutamate receptor, and to inhibit $\mathrm{Ca}^{2+}$ influx and synaptic transmission in olfactory bulb neurons (Trombley and Westbrook, 1992). No antagonists are known to block the action of L-AP4, but L-AP4 does not activate mGluR1 (Houamed et al., 1991). Thus, to determine whether ACPD and L-AP4 activate the same receptor, ACPD $(200 \mu \mathrm{M})$ and L-AP4 $(50 \mu \mathrm{M})$ were sequentially applied to 66 hippocampal neurons. In the majority of the neurons (58 of 66), $I_{\mathrm{Ba}}$ was inhibited only by ACPD, as shown for one neuron in Figure $4 A$. However, in eight neurons, both agonists were equally effective in reducing $I_{\mathrm{Ba}}$. Inhibition was 23.0 $\pm 10.2 \%$ for ACPD and $26.4 \pm 8.1 \%(n=8)$ for L-AP4 (Fig. $4 B$ ). L-AP4 also reduced $I_{\mathrm{Ba}}$ even after several applications of
ACPD had resulted in a progressively smaller ACPD response. These data suggest that L-AP4 and ACPD activate distinct G-protein-coupled receptors, but that only a minority of cultured hippocampal neurons express AP4 receptors that are functionally coupled to calcium channels.

\section{$\mathrm{I}_{B a}$ modulation by $A C P D$ is dependent on $\left[\mathrm{Ca}^{2+}\right]_{\mathrm{i}}$}

The best-characterized action of $\mathrm{mGluR}$ activation is $\mathrm{IP}_{3}-\mathrm{mc}$ diated release of intracellular $\mathrm{Ca}^{2+}$ (Sugiyama, 1987; Furuya et al., 1989), and $\left[\mathrm{Ca}^{2+}\right]_{i}$ may also affect modulation of $\mathrm{K}^{+}$and $\mathrm{Ca}^{2+}$ currents by muscarinic receptors (Marrion et al., 1991; Beech et al., 1992). The dependence of ACPD modulation on intracellular calcium was tested by buffering the patch pipette to $<1 \mathrm{nM}, 30 \mathrm{nM}$, or $100 \mathrm{nM}\left[\mathrm{Ca}^{2+}\right]_{i}$. We waited 5 min after the establishment of whole-cell recording before application of ACPD to allow equilibration of the patch pipette with the cytoplasm. ACPD became more effective as $\mathrm{Ca}^{2+}$ was increased in the patch pipette. The $I_{\mathrm{Ba}}$ inhibition was $15.1 \pm 5.3 \%(n=5)$ at $<1 \mathrm{nM}$, $25.4 \pm 4.7 \%(n=6)$ at $30 \mathrm{nM}$, and $29.6 \pm 10.2 \%(n=5)$ at $100 \mathrm{~nm}\left[\mathrm{Ca}^{2+}\right] i$. The inhibition at $100 \mathrm{~nm}\left[\mathrm{Ca}^{2+}\right]_{i}$ was significantly greater than at $<1 \mathrm{~nm}\left[\mathrm{Ca}^{2+}\right]_{i}(P<0.05)$. There was a larger variance in inhibition at higher $\left[\mathrm{Ca}^{2+}\right]_{i}$, perhaps due to variations in cell dialysis that depend on cell size and access resistance (see Pusch and Nchcr, 1988; Mathias ct al., 1990). We attempted to determine whether release of $\mathrm{Ca}^{2+}$ from intracellular stores contributed to the modulation using thapsigargin ( $1 \mu \mathrm{M} ; n=6$ ), a selective inhibitor of the microsomal $\mathrm{Ca}^{2+}$-ATPase (Thastrup et al., 1990). However, thapsigargin caused an irreversible inhibition of $I_{\mathrm{Ba}}$ even in the absence of ACPD (not shown). Release of intracellular $\mathrm{Ca}^{2+}$ from caffeinesensitive store can also decrease $\mathrm{Ca}^{2+}$ currents (Thayer et al., 1988; Kramer et al., 1991), and the effects of caffeine (10 mM; $n=5$ ) were additive to those of ACPD (not shown). These results suggest that $I_{\mathrm{Ba}}$ modulation by ACPD is dependent on 

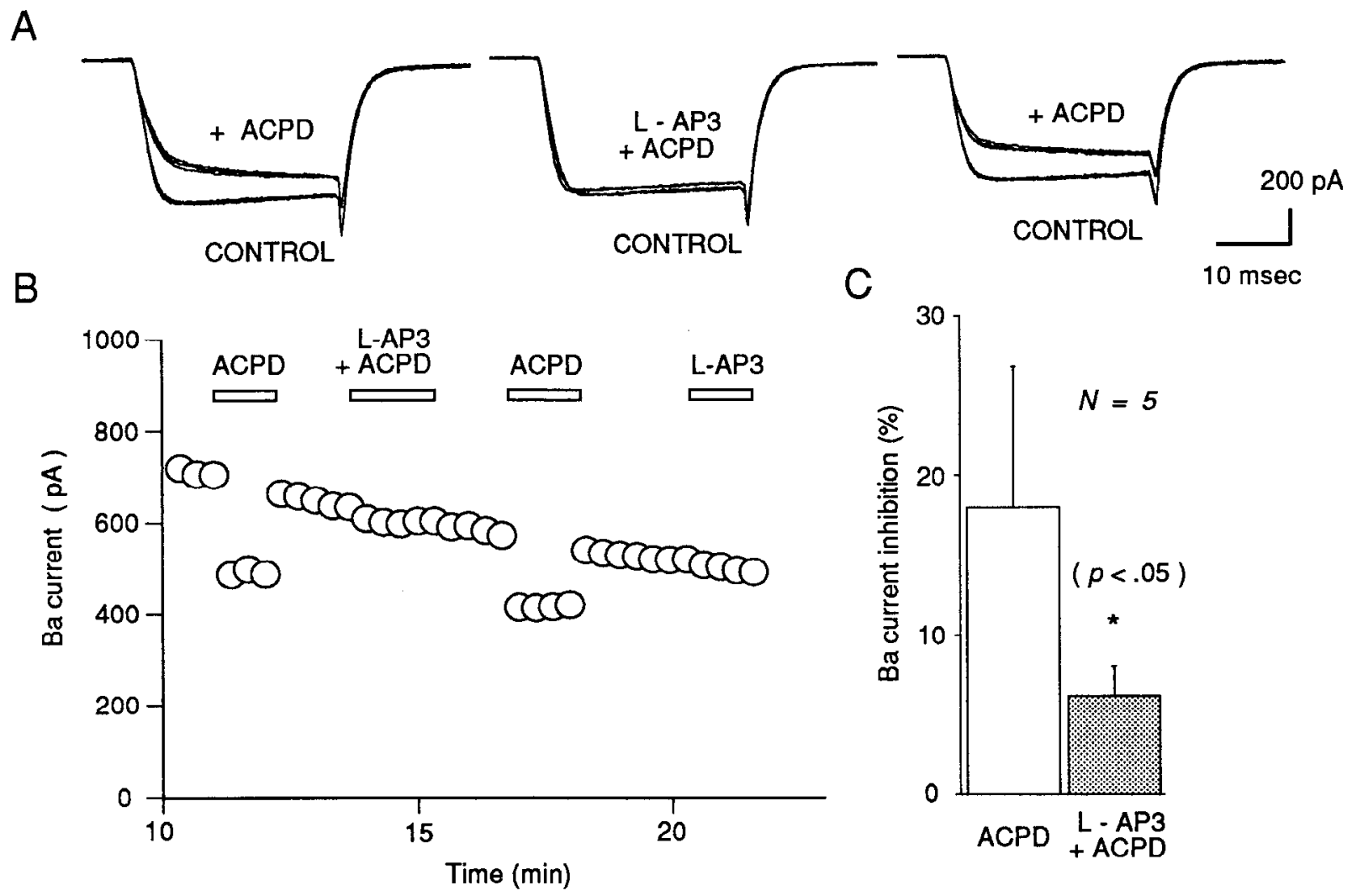

C

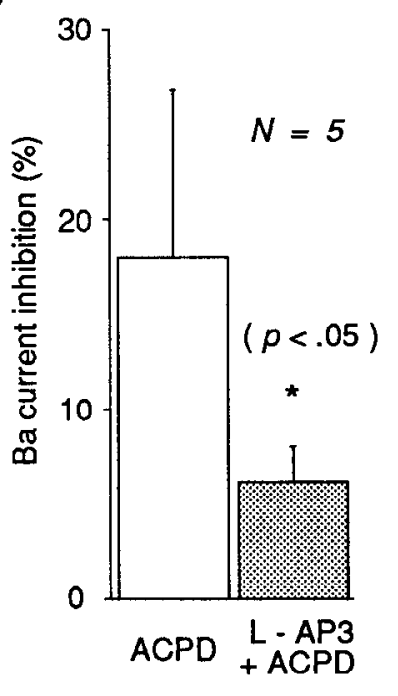

Figure 3. L-AP3 antagonizes ACPD inhibition of $I_{\mathrm{Ba}} . A, I_{\mathrm{Ba}}$ before, during, and after washout of $50 \mu \mathrm{M}$ ACPD are superimposed. The addition of $1 \mathrm{mM}$ L-AP3 completely blocked the reduction in $I_{\mathrm{Ba}}$ by ACPD (middle), and was rapidly reversible (right). Holding potential was $-60 \mathrm{mV}$. $B$, Plot of $I_{\mathrm{B}}$ for the neuron shown in $A$. Applications of $50 \mu \mathrm{M} \mathrm{ACPD}$ and $1 \mathrm{~mm}$ L-AP3 are indicated by bars. L-AP3 had no direct effect on $I_{\mathrm{Ba}}$ at $1 \mathrm{mM}$ in the presence of DL-AP5 $(100 \mu \mathrm{M})$ and 7-chlorokynurenic acid (500 nM) to block NMDA receptors. $C$, Percentage inhibition of $I_{\mathrm{Ba}}$ by ACPD $(50 \mu \mathrm{M})$ before and after L-AP3 (1 $\mathrm{mm})$ application.

the steady state $\left[\mathrm{Ca}^{2+}\right]_{i}$, although our data are not sufficient to exclude an additional contribution from intracellular $\mathrm{Ca}^{2+}$ stores.

The kinetics of $I_{\mathrm{Ba}}$ modulation were also dramatically affected by the $\mathrm{Ca}^{2+}$ concentration in the pipette. Figure 5 compares the time course of ACPD action with pipettes containing either $<1$ nM $\left[\mathrm{Ca}^{2+}\right]_{i}$ (Fig. $5 A$ ) or $100 \mathrm{~nm}\left[\mathrm{Ca}^{2+}\right]_{i}$ (Fig. $5 C$ ). At the low concentration of $\left[\mathrm{Ca}^{2+}\right]_{i}$, ACPD modulation had both a rapid onset and recovery (Fig. $5 A$ ). For the neuron shown in Figure

A

B
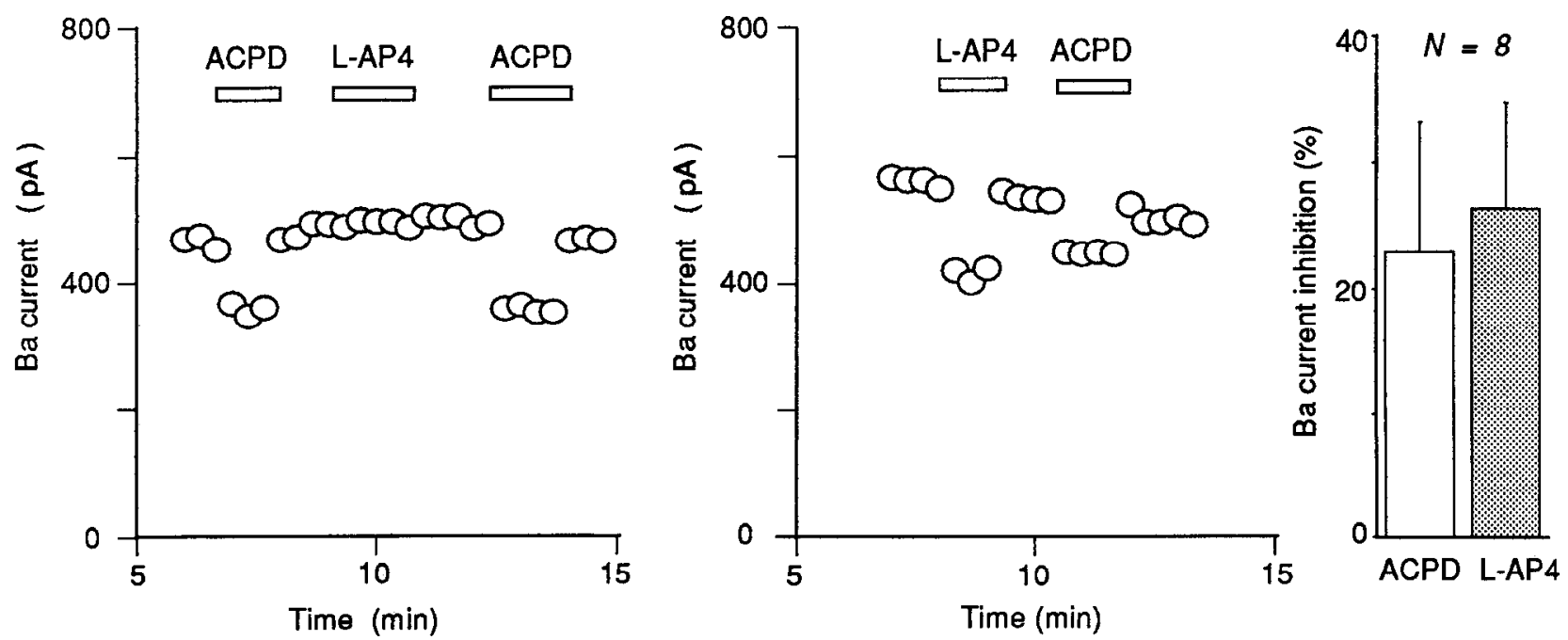

Figure 4. Inhibition of $I_{\mathrm{Ba}}$ by L-AP4 and ACPD involves different receptors. $A$, Both ACPD (200 $\left.\mu \mathrm{M}\right)$ and L-AP4 (50 $\left.\mu \mathrm{M}\right)$ were applied to 66 neurons. In the majority of the neurons ( 58 of 66$), I_{\mathrm{Ba}}$ was inhibited only by ACPD as shown for this neuron. $B$, However in the remaining eight neurons, both L-AP4 $(50 \mu \mathrm{M})$ and ACPD were effective as shown for this neuron (left). The percentage inhibition of $I_{\mathrm{Ba}}$ by $\mathrm{L}-\mathrm{AP} 4$ and ACPD was similar (right). 
A

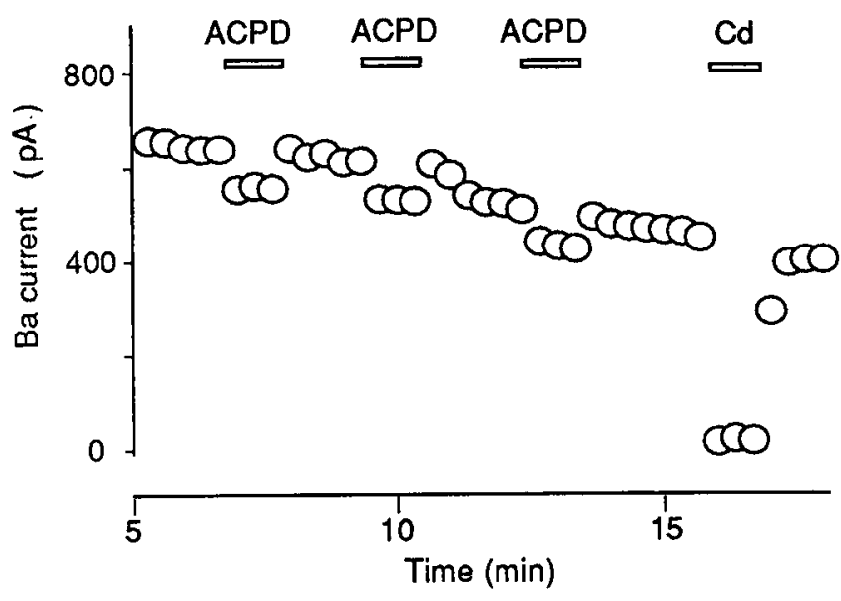

B

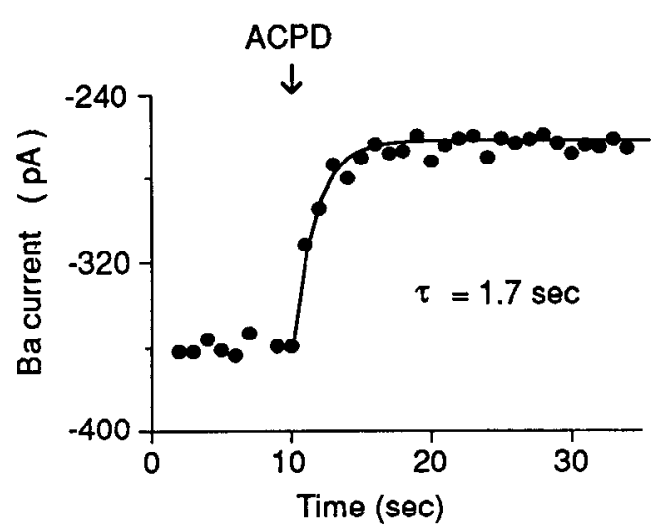

C

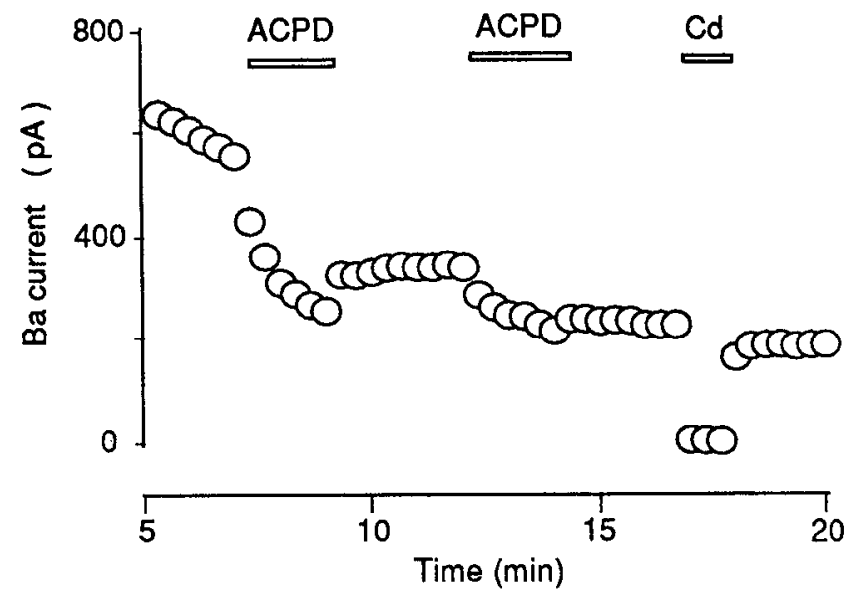

$\mathrm{D}$

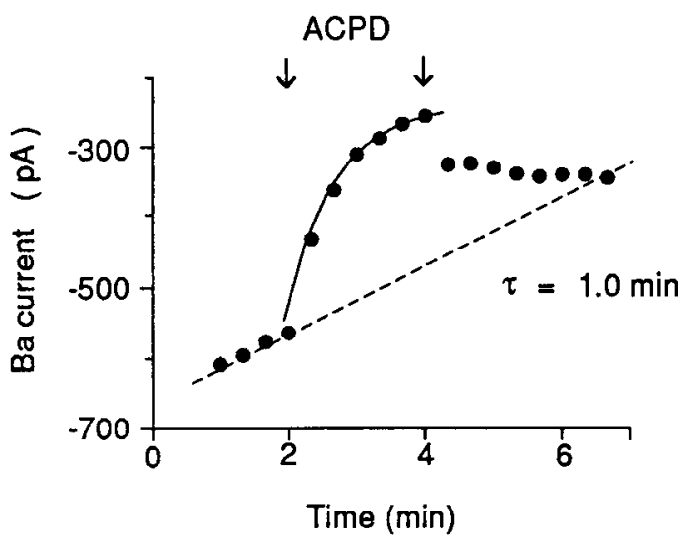

Figure 5. Increases in $\left[\mathrm{Ca}^{2+}\right]$, revealed a slow component of $I_{\mathrm{Ba}}$ inhibition. $I_{\mathrm{Ba}}$ was recorded with patch pipettes buffered to either low Ca ${ }^{2+}(<1$ nM) or high $\mathrm{Ca}^{2+}(100 \mathrm{nM})$ with BAPTA $/ \mathrm{Ca}^{21}$ mixtures. $A$, With $\left[\mathrm{Ca}^{2+}\right]_{i}$ buffered to $<1 \mathrm{nM}, I_{\mathrm{Ba}}$ inhibition evoked by application of ACPD (200 $\mu \mathrm{M})$ showed rapid onset and recovery. ACPD was applied $5 \mathrm{~min}$ after establishment of whole-cell configuration to allow equilibration of the buffer with the cytoplasm. $B$, The rapid onset was fitted with a single exponential with a time constant of 1.7 sec. $I_{\mathrm{Ba}}$ was elicited every 1 sec by a 10 msec step from $-60 \mathrm{mV}$ to $0 \mathrm{mV}$, and leak subtracted using $100 \mu \mathrm{M} \mathrm{Cd}^{2+}$. ACPD (200 $\left.\mu \mathrm{M}\right)$ was applied at time as indicated by the arrow. $C$, In another neuron, with $\left[\mathrm{Ca}^{2+}\right]_{i}$ buffered to $100 \mathrm{nM}$, the onset of inhibition was markedly slowed. Recovery following removal of ACPD showed both a fast and a slow component. $D$, The onset of the slow component was measured with $I_{\mathrm{Ba}}$ evoked every 20 sec during a long application ( 2 min) of ACPD (200 $\mu \mathrm{M}$; arrows). A single exponential curve $(t=1 \mathrm{~min})$ was fitted to the onset.

$5 B$, the rapid onset of inhibition was fitted with a single exponential curve $(t=1.7 \mathrm{sec})$. In contrast, with the pipette buffered to $100 \mathrm{nM}\left[\mathrm{Ca}^{2+}\right]_{i}, I_{\mathrm{Ba}}$ continued to decrease during application of ACPD (Fig. $5 C$ ). The time constant for the onset of the slow phase was $3.0 \pm 1.7 \mathrm{~min}(n=5$; Fig. $5 D)$. We were unable to resolve adequately a fast component of the onset because voltage jumps were performed only at $20 \mathrm{sec}$ intervals; this was necessary to prevent rapid calcium current rundown in high- $\left[\mathrm{Ca}^{2+}\right]_{i}$ solutions. However, when ACPD was rapidly washed out, both a fast and slow component of recovery were apparent (Fig. $5 C, D$ ). In most cases recovery of the slow component was incomplete. Subsequent ACPD application often revealed a smaller slow component, perhaps due to incomplete recovery from the prior application.

\section{$A C P D$ inhibits both dihydropyridine-sensitive and $\omega-C g T x-$ sensitive $\mathrm{Ca}^{2+}$ channels}

In rat hippocampal neurons, at least three types of high-threshold $\mathrm{Ca}^{2+}$ channels, N-, L-, and P-type (non-L, non-N), have been described (Mogul and Fox, 1991; Regan et al., 1991). L-type current is blocked by dihydropyridine (DHP) antagonists such as nifedipine whereas $\mathrm{N}$-type currents are irreversibly blocked by $\omega$-CgTx (e.g., Hess, 1990). In our experiments, $32.3 \pm 10.6 \%$ of $I_{\mathrm{Ba}}$, elicited from a holding potential of $-60 \mathrm{mV}$, was irreversibly blocked by $\omega$-CgTx $(0.5-1 \mu \mathrm{M}), 18.1 \pm 8.1 \%$ of the remaining current was sensitive to nifedipine $(1 \mu \mathrm{M})$, and the remaining $30-50 \%$ was therefore of the non- $\mathrm{L}$, non- $\mathrm{N}$ type ( $n$ $=20$ ). In some cells, apparently unequal proportions of $\mathrm{Ca}^{2+}$ channels ( $<10 \%$ of L-type and $50 \% \mathrm{~N}$-type channel) were observed.

In order to determine the $\mathrm{Ca}^{2+}$ channel subtype that was inhibited by ACPD, $I_{\mathrm{Ba}}$ was evoked before and after block of $\mathrm{N}$-type current with $\omega$-CgTx using patch pipettes buffered with EGTA $(\mathrm{pCa}-8)$. As shown in Figure $6 A$, although $\omega$-CgTx block was irreversible, subsequent application of ACPD produced a smaller, but clearly measurable, decrease in $I_{\mathrm{Ba}}$. In five experiments, ACPD $(200 \mu \mathrm{M})$ inhibited $I_{\mathrm{Ba}}$ by $17.4 \pm 3.2 \%$ before $\omega$-CgTx application compared to $6.8 \pm 1.2 \%$ after $\omega-\mathrm{CgTx}$. Thus, ACPD inhibits $\mathrm{N}$-type channels as well as a residual current of either the $\mathrm{L}$ or the non- $\mathrm{L}$, non-N type. To test whether ACPD also blocks L-type channels, ACPD was applied in the presence of nifedipine $(1 \mu \mathrm{M})$. As shown in Figure $6 B$, nifedipine blocked part of $I_{\mathrm{Ba}}$ and reduced the effect of ACPD, suggesting that L-type currents are also sensitive to inhibition by an mGluR. 
The reduction in $I_{\mathrm{Ba}}$ modulation could not be attributed to channel rundown, as ACPD was effective following washout of nifedipine. ACPD inhibited $I_{\mathrm{Ba}}$ by $17.0 \pm 6.4 \%$ before nifedipine application, while ACPD inhibited DHP-resistant currents by $8.6 \pm 0.9 \%$, and by $14.4 \pm 2.4 \%(n=4)$ following washout. The prolongation of $\mathrm{Ca}^{2+}$ tail currents by $\mathrm{DHP}$ agonists has also been used to examine modulation of L-type channels (e.g., Plummer et al., 1991); however, the presence of dendrites on cultured neurons prevented adequate time resolution for tail current analysis.

\section{Discussion}

Our results demonstrate that $\mathrm{Ca}^{2+}$ channel modulation by G-protein-coupled glutamate receptors involves distinct receptor subtypes activated by L-AP4 and ACPD. The $\mathrm{EC}_{50}$ values for ACPD and antagonism by L-AP3 are consistent with activation of an mGluR. However, inhibition of $I_{\mathrm{Ba}}$ by ACPD had two kinetic components; the fast component was similar to the membrane-delimited effects of activated G-proteins, whereas the slow component was dependent on the steady state level of $\left[\mathrm{Ca}^{2+}\right]_{i}$. Both DHP-sensitive and $\omega-\mathrm{CgTx}$-sensitive $\mathrm{Ca}^{2+}$ channels were modulated by ACPD.

\section{The $m G l u R$ responsible for $\mathrm{Ca}^{2+}$ current modulation}

Until recently the action of glutamate analogs on second messenger-coupled responses was considered as resulting from activation of a single mGluR. However, molecular cloning studies have revealed at least five mGluR subtypes, although the role of these subtypes in specific cellular functions is still unclear. Several glutamate agonists including quisqualate, L-AP4, ibotenate, and L-glutamate inhibit high-threshold $\mathrm{Ca}^{2+}$ currents (Lester and Jahr, 1990; Trombley and Westbrook, 1992). Quisqualate is a potent agonist for mGluR 1 and mGluR5, but has a low affinity for mGluR2; L-glutamate, the endogenous agonist for mGluRs, is relatively nonselective. Because ACPD is a selective agonist for mGluR1, -2, and -5 (Masu et al., 1991; Abe et al., 1992; Tanabe et al., 1992), our results are consistent with modulation of $\mathrm{Ca}^{2+}$ channels by one of these mGluR receptor subtypes. This is also supported by recent studies in CA3 and cortical neurons (Sayer et al., 1992; Swartz and Bean, 1992a). However, L-AP4 does not activate mGluR 1, -2, or -5 (Houamed et al., 1991; Abe et al., 1992; Tanabe et al., 1992), suggesting the involvement of an additional "AP4" receptor, possibly mGluR4 (Tanabe et al., 1993).

Our data also suggest that two distinct G-protein-coupled glutamate receptors modulate $\mathrm{Ca}^{2+}$ channels in hippocampal neurons. Only $10 \%$ of the hippocampal neurons tested were sensitive to both L-AP4 and ACPD. This is consistent with the low sensitivity of hippocampal pathways to presynaptic inhibition by L-AP4, except for the neurons projecting into the dentate gyrus via the lateral perforant pathway (reviewed in Mayer and Westbrook, 1987). This contrasts with cultured ulfactory bulb neurons, where the majority of mitral/tufted cells are sensitive to L-AP4 (Trombley and Westbrook, 1992). The small number of AP4-sensitive cells precluded testing the additivity of AP4 and ACPD in the presence of GTP $\gamma \mathrm{S}$, a method useful for distinguishing separate populations of receptors. However, consistent with involvement of separate receptors, L-AP4 inhibited $I_{\mathrm{Ba}}$ in hippocampal neurons even after ACPD inhibition markedly declined following multiple applications.

It is not yet possible to distinguish mGluR subtypes with antagonists. In particular, prior studies with the putative $\mathrm{mGluR}$
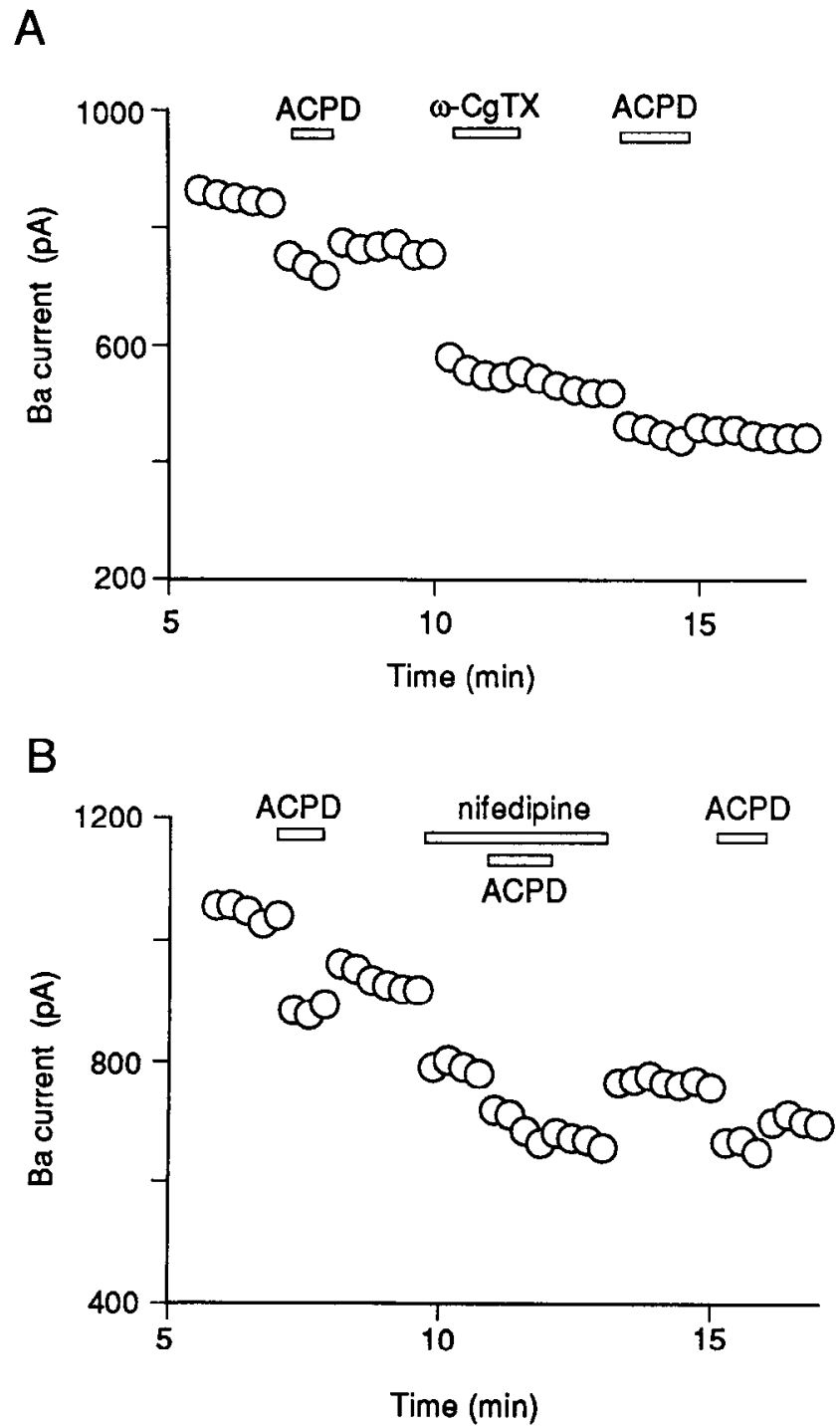

Figure 6. ACPD acts on both $\omega$-CgTx-sensitive and DHP-sensitive $\mathrm{Ba}^{2+}$ currents. $A$, ACPD $(200 \mu \mathrm{M})$ was applied before and after irreversible block of N-type channels by $\omega$-CgTx $(1 \mu \mathrm{M}) . \omega$-CgTx blocked $25 \%$ of $I_{\mathrm{Ba}}$ in this neuron and reduced the ACPD-sensitive current from $110 \mathrm{pA}$ to $65 \mathrm{pA}$, suggesting that both $\omega-\mathrm{CgTx}$-sensitive and -insensitive currents are affected by mGluRs. $B$, In another neuron, ACPD (200 $\mu \mathrm{M})$ inhibition was partially blocked during simultaneous application of nifedipine $(1 \mu \mathrm{M})$, consistent with inhibition of L-type channels by ACPD. The $I_{\mathrm{Ba}}$ inhibition returned to control levels following washout of nifedipine. Patch pipettes contained $11 \mathrm{~mm}$ EGTA and $1 \mathrm{mM} \mathrm{Ca}^{2+}$. $I_{\mathrm{Ba}}$ was evoked by voltage jumps to $0 \mathrm{mV}$ from a holding potential of $-60 \mathrm{mV}$.

antagonist L-AP3 have produced variable results. L-AP3 blocks mGluR-stimulated $\mathrm{IP}_{3}$ production in hippocampal slices (Schoepp et al., 1990b) as well as in Xenopus oocytes expressing mGluR cDNAs in some experiments (Houamed et al., 1991), but not in others (Masu et al., 1991; Abe et al., 1992; Tanabe et al., 1992). Unlike the noncompetitive action previously reported (Schoepp et al., 1990b), the effect of L-AP3 in our experiments could be overcome by higher concentrations of ACPD. We have made similar observations in Xenopus oocytes injected with hippocampal polyA + mRNA or mGluR1 cDNA (G. L. Westbrook, unpublished observation), suggesting that L-AP3 is a competitive, albeit weak, mGluR antagonist. Thus, L-AP3 is likely to be ineffective if high concentrations of agonist are used 
or in the presence of "spare" receptors, that is, if less than full receptor occupancy results in a maximal response.

\section{Coupling of mGluRs to $\mathrm{Ca}^{2+}$ channels}

It has been proposed that mGluR and AP4 receptors inhibit $\mathrm{Ca}^{2+}$ channels via a membrane-delimited pathway (Lester and Jahr, 1990; Swartz and Bean, 1992a; Trombley and Westbrook, 1992). Membrane-delimited coupling to high-threshold $\mathrm{Ca}^{2+}$ channels appears to be a common general mechanism for $\mathrm{G}$-protein-coupled receptors (reviewed in Hille, 1992). This coupling mechanism has several characteristics features including prominent slowing of $\mathrm{Ca}^{2+}$ current activation kinetics (Bean, 1989; Elmslie et al., 1990) and kinetics faster than expected for a diffusible second messenger system (Jones, 1991; Beech et al., 1992). For example, muscarinic receptors in cardiac myocytes open $\mathrm{K}(\mathrm{ACh})$ channels via PTX-sensitive pathway with a latency of 30-150 msec (Yatani and Brown, 1989), and the fast muscarinic inhibition of $\mathrm{Ca}^{2+}$ currents on superior cervical ganglion neurons occurs in less than $1 \mathrm{sec}$ (Bernheim et al., 1991; Beech et al., 1992). ACPD inhibition of $\mathrm{Ca}^{2+}$ currents in our experiments shared these features when $\left[\mathrm{Ca}^{2+}\right]_{i}$ was tightly buffered, consistent with a membrane-delimited action $\mathrm{Ca}^{2+}$ channel activation.

Although the G-protein involved in the fast component of inhibition was PTX sensitive in our experiments, others have been unable to block mGluR inhibition with PTX (Lester and Jahr, 1990; Swartz and Bean, 1992a). PTX does block mGluR2induced inhibition of cAMP formation as well as $40 \%$ of $\mathrm{IP}_{3}$ synthesis by mGluR 1 , but has only a small effect on $\mathrm{IP}_{3}$ synthesis by mGluR5 (Masu et al., 1991; Abe et al., 1992; Tanabe et al., 1992). Thus, it is possible that more than one G-protein is involved in $\mathrm{Ca}^{2+}$ channel modulation by mGluks, as has been reported for muscarinic receptors (see, e.g., Beech et al., 1992). The stimulation of independent second messenger pathways by mGluR 1 in CHO cells provides further evidence for such coupling diversity (Aramori and Nakanishi, 1992).

\section{Dependence of $\mathrm{Ca}^{2+}$ channel modulation on $\left[\mathrm{Ca}^{2+}\right]_{\mathrm{i}}$}

In addition to the fast component of $\mathrm{Ca}^{2+}$ channel inhibition, increases in the steady state $\left[\mathrm{Ca}^{2+}\right]_{i}$ revealed a slow component of inhibition by ACPD that had an onset time constant of $\approx 3$ min and a equally slow recovery rate. Because we used $\mathrm{Ba}^{2+}$ as the charge carrier, transmembrane $\mathrm{Ca}^{2+}$ influx could not be responsible for the slow inhibitory component. Although mGluR1 and mGluR5 stimulate release of intracellular $\mathrm{Ca}^{2+}$ stores, the rise time of the slow component was much longer than the time course of cytoplasmic $\mathrm{Ca}^{2+}$ transients evoked by quisqualate in $\mathrm{Ca}^{2+}$-free solutions (ca. $3 \mathrm{sec}$; Furuya et al., 1989). Likewise, in the absence of extracellular $\mathrm{Ca}^{2+},\left[\mathrm{Ca}^{2+}\right]_{i}$ transients disappear with multiple agonist applications, presumably due to depletion of stores (Murphy and Miller, 1988; Furuya et al., 1989). Thus, the $\mathrm{Ca}^{2+}$ dependence would not appear to be simply due to facilitation of $\mathrm{IP}_{3}$-mediated release of intracellular $\mathrm{Ca}^{2+}$. The $\left[\mathrm{Ca}^{2+}\right]_{i}$ dependence of the slow component of inhibition is likely to explain the $\mathrm{Ca}^{2+}$ dependence observed with quisqualate-induced depression of $\mathrm{Ca}^{2+}$ currents (Lester and Jahr, 1990). However, the mechanism of action of $\mathrm{Ca}^{2+}$ remains unclear. Both mGluR 1 and mGluR5 would be expected to activate protcin kinase $\mathrm{C}$ ( $\mathrm{PKC}$ ), and $\mathrm{PKC}$ activators have been shown to decrease whole-cell $\mathrm{Ca}^{2+}$ currents (Doerner et al., 1988; Rane et al., 1989; Plummer et al., 1991). However, this does not appear to explain ACPD modulation of $\mathrm{Ca}^{2+}$ currents, as
PKC enhances $\mathrm{Ca}^{2+}$ currents while occluding mGluR-mediated inhibition of $\mathrm{N}-$ typc $\mathrm{Ca}^{2+}$ currents in CA3 ncurons (Swartz et al., 1993).

The distinct kinetic components of ACPD modulation in our experiments are strikingly similar to modulation of $\mathrm{Ca}^{2+}$ channels in sympathetic neurons (Bernheim et al., 1991; Beech et al., 1992). In sympathetic neurons, muscarinic receptors mediate a fast membrane-delimited inhibition and a slow inhibition dependent on the steady state $\left[\mathrm{Ca}^{2+}\right]_{i}$, whereas noradrenaline activates only the fast component. In our experiments the increase in percentage inhibition in high $\left[\mathrm{Ca}^{2+}\right]_{i}$ also suggests that both fast and slow mechanisms are involved, although we were unable to resolve the fast component of the onset in high $\left[\mathrm{Ca}^{2+}\right]_{i}$ due to the limited sampling rate. However two components were apparent in the recovery. An alternative possibility, that Ca slows a single kinetic process, is thus unlikely. The second messenger mediating the slow component is unknown, but does not appear to involve release of intracellular $\mathrm{Ca}^{2+}, \mathrm{PKC}$, or cyclic nucleotides (Bernheim et al., 1991). It has been suggested that a $\mathrm{Ca}^{2+}$-dependent phosphatase could be this messenger (Armstrong and White, 1992).

\section{$\mathrm{Ca}^{2+}$ channel subtypes}

Both $\omega-\mathrm{CgTx}$-sensitive as well as DHP-sensitive $\mathrm{Ca}^{2+}$ channels were inhibited by ACPD. Many neurotransmitters and neuropeptides can inhibit $\mathrm{Ca}^{2+}$ channels, although in most cases $\mathrm{N}$-type channels appear to be the target (Tsien et al., 1988; Hess, 1990). DHP-sensitive $\mathrm{Ca}^{2+}$ channels are also modulated by neurotransmitters. The best studied is the enhancement of L-type channels in cardiac myocytes by cAMP-dependent protein kinase (for a review, see Birnbaumer et al., 1990). Activation of PKC has been reported to increase or decrease $\mathrm{L}$-type $\mathrm{Ca}^{2+}$ current in cardiac cells (Lacerda et al., 1988), and leutinizing hormonereleasing hormone inhibits $\mathrm{L}$ - as well as $\mathrm{N}$-type $\mathrm{Ca}^{2+}$ channels in frog sympathetic neurons (Bley and Tsien, 1990). Sayer et al. (1992) reported that trans-ACPD selectively inhibits L-type channels in cortical neurons, while Swartz and Bean (1992a) reported that ACPD selectively inhibits N-type channels in CA3 hippocampal neurons. The kinetics of $\mathrm{N}$-type channel inhibition were similar to the fast component seen in our experiments. As these experiments were done with tightly buffered $\left[\mathrm{Ca}^{2+}\right]_{i}$, this may explain the lack of a slow component of inhibition. Taken together, these results are consistent with inhibition of $\mathrm{N}$-type channels primarily by the fast mechanism whereas L-type channels are only affected by the slow inhibitory process. This would also be analogous to muscarinic receptors in sympathetic neurons (Mathie et al., 1992).

\section{Functional significance}

Inhibition of $\mathrm{N}$-type $\mathrm{Ca}^{2+}$ channels is considered a likely mechanism for regulation of transmitter release by presynaptic autoreceptors (e.g., Hirning et al., 1988; Holz et al., 1988; Lipscombe et al., 1989; Bley and Tsien, 1990). The role of L-type currents in transmitter release is less clear. L-AP4 and transACPD can inhibit transmitter release (e.g., Forsythe and Clements, 1990; Baskys and Malenka, 1991; Lovinger, 1991; Trombley and Westbrook, 1992). We have confirmed that $\omega$-CgTx blocks spontaneous EPSCs in cultured hippocampal neurons while nifedipine has little effect. However, in the presence of TTX $(1 \mu \mathrm{M})$, miniature EPSCs are more effectively blocked by nifedipine than by $\omega-\mathrm{CgTx}$ (Y. Sahara, unpublished observation). Depression of transmitter release also results from 
an increase in $\mathrm{K}^{+}$conductance in presynaptic terminals as suggested by Cox and Dunlap (1992), and ACPD also modulates at least two separate $\mathrm{K}^{+}$conductances, $\mathrm{Ca}^{2+}$-activated $\mathrm{K}^{+}\left(I_{\mathrm{AHP}}\right)$ and $I_{M}$ (Charpak et al., 1990).

Our results add further to this complexity in that $\mathrm{Ca}^{2+}$ channel modulation by mGluRs appears to involve both multiple receptors and distinct kinetic components. This remarkable diversity provides an array of possible cellular effects as has been suggested for other G-protein-coupled receptors (e.g., Hille, 1992). A critical variable in sorting out this complexity is the time course of transmitter during normal synaptic transmission and the cellular location of mGluRs. Glutamate is present at high concentrations in the synaptic cleft for only brief periods (e.g., $\approx 1 \mathrm{~mm}$ for $1 \mathrm{msec}$; Clements et al., 1992). As glutamate has a relatively low affinity for mGluRs (Schoepp et al., 1990a), it seems unlikely these receptors will be significantly activated during normal synaptic activity unless they are located within the synaptic cleft. If mGluRs are more uniformly distributed on the membrane surface, activation may occur only during intense or repetitive synaptic activity.

\section{References}

Abe T, Sugihara H, Nawa H, Shigemoto R, Mizuno N, Nakanishi S (1992) Molecular characterization of a novel metabotropic glutamate receptor mGluR5 coupled to inositol phosphate/ $\mathrm{Ca}^{2+}$ signal transduction. J Biol Chem 267:13361-13368.

Aramori I, Nakanishi S (1992) Signal transduction and pharmacological characteristics of a metabotropic glutamate receptor, mGluR1, in transfected CHO cells. Neuron 8:757-765.

Armstrong DL, White RE (1992) An enzymatic mechanism for potassium channel stimulation through pertussis-toxin-sensitive $G$ proteins. Trends Neurosci 15:403-408.

Baskys A, Malenka RC (1991) Agonists at metabotropic glutamate receptors presynaptically inhibit EPSCs in neonatal rat hippocampus. J Physiol (Lond) 444:687-701.

Bean BP (1989) Neurotransmitter inhibition of neuronal calcium currents by changes in channel voltage dependence. Nature 340:153156.

Beech DJ, Bernheim L, Hille B (1992) Pertussis toxin and voltage dependence distinguish multiple pathways modulating calcium channels of rat sympathetic neurons. Neuron 8:97-106.

Bernheim L, Beech DJ, Hille B (1991) A diffusible second messenger mediates one of the pathways coupling receptors to calcium channels in rat sympathetic neurons. Neuron 6:859-867.

Birnbaumer L, Abramowitz J, Brown AM (1990) Receptor-effector coupling by $\mathrm{G}$ proteins. Biochem Biophys Acta 1031:163-224.

Bley KR, Tsien RW (1990) Inhibition of $\mathrm{Ca}^{2+}$ and $\mathrm{K}^{+}$channels in sympathetic neurons by neuropeptides and other ganglionic transmitters. Neuron 2:379-391.

Charpak S, Gähwiler BH, Do KQ, Knöpfel T (1990) Potassium conductances in hippocampal neurons blocked by excitatory amino-acid transmitters. Nature 347:765-767.

Chernevskaya NI, Obukhov AG, Krishtal OA (1991) NMDA receptor agonists selectively block $\mathrm{N}$-type calcium channels in hippocampal neurons. Nature 349:418-420.

Clements JD, Lester RAJ, Tong G, Jahr CE, Westbrook GL (1992) The time course of glutamate in the synaptic cleft. Science 258:14981501 .

Collingridge GL, Lester RAJ (1989) Excitatory amino acid receptors in the vertebrate central nervous system. Pharmacol Rev 40:143-210.

Cox DH, Dunlap K (1992) Pharmacological discrimination of N-type from L-type calcium current and its selective modulation by transmitters. J Neurosci 12:906-914.

Desai MA, Conn PJ (1991) Excitatory effects of ACPD receptor activation in the hippocampus are mediated by direct effects on pyramidal cells and blockade of synaptic inhihition. J Neurophysiol 66 : $40-52$.

Doerner D, Pitler TA, Alger BE (1988) Protein kinase C activators block spccific calcium and potassium current components in isolated hippocampal neurons. J Neurosci 8:4069-4078.
Elmslie KS, Zhou W, Jones SW (1990) LHRH and GTP- $\gamma-S$ modify calcium current activation in bullfrog sympathetic neurons. Neuron 5:75-80.

Forsythe ID, Clements JD (1990) Presynaptic glutamate receptors depress excitatory monosynaptic transmission between mouse hippocampal neurones. J Physiol (Lond) 429:1-16.

Furuya S, Ohmori II, Shigemoto T, Sugiyama II (1989) Intracellular calcium mobilization triggered by a glutamate receptor in rat cultured hippocampal cells. J Physiol (Lond) 414:539-548.

Hess P (1990) Calcium channels in vertebrate cells. Annu Rev Neurosci $13: 337-356$

Hille B (1992) G Protein-coupled mechanisms and nervous signaling. Neuron 9:187-195.

Hirning LD, Fox AP, McCleskey EW, Olivera BM, Thayer SA, Miller $\mathrm{RJ}$, Tsien RW (1988) Dominant role of $\mathrm{N}$-type $\mathrm{Ca}^{2+}$ channels in evoked release of norepinephrine from sympathetic neurons. Science 239:57-61.

Holz GG, Dunlap K, Kream RM (1988) Characterization of the electrically evoked release of substance $P$ from dorsal root ganglion neurons: methods and dihydropyridine sensitivity. J Neurosci 8:463471 .

Houamed KM, Kuijper JL, Gilbert TL, Haldeman BA, O'Hara PJ, Mulvihill ER, Almers W, Hagen FS (1991) Cloning, expression, and gene structure of a $\mathrm{G}$ protein-coupled glutamate receptor from rat brain. Science 252:1318-1321.

Irving AJ, Schofield JG, Watkins JC, Sunter DC, Collingridge GL (1990) $1 S, 3 R$-ACPD stimulates and $\mathrm{x}$-AP3 blocks $\mathrm{Ca}^{2+}$ mobilization in rat cerebellar neurons. Eur J Pharmacol 186:363-365.

Jones SW (1991) Time course of receptor-channel coupling in frog sympathetic neurons. Biophys J 60:502-507.

Kramer RH, Kaczmarek LK, Levitan ES (1991) Neuropeptide inhibition of voltage-gated calcium channels mediated by mobilization of intracellular calcium. Neuron 6:557-563.

Lacerda AE, Rampe D, Brown AM (1988) Effects of protein kinase $\mathrm{C}$ activators on cardiac $\mathrm{Ca}^{2+}$ channels. Nature 335:249-251.

Legendre P, Westbrook GL (1990) The inhibition of single $N$-methylD-aspartate-activated channels by zinc ions on cultured rat neurones. J Physiol (Lond) 429:429-449.

Lester RAJ, Jahr CE (1990) Quisqualate receptor-mediated depression of calcium currents in hippocampal neurons. Neuron 4:741-749.

Lester RAJ, Clements JD, Westbrook GL, Jahr CE (1990) Channel kinetics determine the time course of NMDA receptor-mediated synaptic currents. Nature 346:565-567.

Lipscombe D, Kongsamut S, Tsien RW (1989) $\alpha$-Adrenergic inhibition of sympathetic neurotransmitter release mediated by modulation of N-type calcium-channel gating. Nature 340:639-642.

Lovinger DM (1991) Trans-1-aminocyclopentane-1,3-dicarboxylicacid $(t$-ACPD) decreases synaptic excitation in rat striatal slices through a presynaptic action. Neurosci Lett 129:17-21.

Marrion NV, Zucker RS, Marsh SJ, Adams PR (1991) Modulation of M-current by intracellular $\mathrm{Ca}^{2+}$. Neuron 6:533-545.

Masu M, Tanabe Y, Tsuchida K, Shigemoto R, Nakanishi S (1991) Sequence and expression of a metabotropic glutamate receptor. Nature 349:760-765.

Mathias RT, Cohen IS, Oliva C (1990) Limitations of the whole cell patch clamp technique in the control of intracellular concentrations. Biophys J 58:759-770.

Mathie A, Bernheim L, Hille B (1992) Inhibition of N- and L-type calcium channels by muscarinic receptor activation in rat sympathetic neurons. Neuron 8:907-914.

Mayer ML, Westbrook GL (1987) The physiology of excitatory amino acids in the vertebrate central nervous system. Prog Neurobiol 28 197-276.

Mintz IM, Adams ME, Bean BP (1992) P-Type calcium channels in rat central and peripheral neurons. Neuron 9:85-95.

Mogul DJ, Fox AP (1991) Evidence for multiple types of $\mathrm{Ca}^{2+}$ channels in acutely isolated hippocampal CA3 neurones of the guinea-pig. J Physiol (Lond) 433:259-281.

Murphy SN, Miller RJ (1988) A glutamate receptor regulates $\mathrm{Ca}^{2+}$ mobilization in hippocampal neurons. Proc Natl Acad Sci USA 85: 8737-8741.

Plummer MR, Rittenhouse A, Kanevsky M, Hess P (1991) Neurotransmitter modulation of calcium channels in rat sympathctic ncurons. J Neurosci 11:2339-2348. 
Pusch M, Neher E (1988) Rates of diffusional exchange between small cells and a measuring patch pipette. Pfluegers Arch 411:204-211.

Rane SG, Walsh MP, McDonald JR, Dunlap K (1989) Specific inhibitors of protein kinase $\mathrm{C}$ block transmitter-induced modulation of sensory neuron calcium current. Neuron 3:239-245.

Regan LJ, Sah DWY, Bean BP (1991) $\mathrm{Ca}^{2+}$ channels in rat central and peripheral neurons: high-threshold current resistant to dihydropyridine blockers and $\omega$-conotoxin. Neuron 6:269-280.

Sahara Y, Westbrook GL (1991) trans-ACPD blocks high threshold calcium currents on cultured hippocampal neurons. Soc Neurosci Abstr 17:1168.

Sayer RJ, Schwindt PC, Crill WE (1992) Metabotropic glutamate receptor-mediated suppression of L-type calcium current in acutely isolated neocortical neurons. J Neurophysiol 68:833-842.

Schoepp D, Bockaert J, Sladeczek F (1990a) Pharmacological and functional characteristics of metabotropic excitatory amino acid receptors. Trends Pharmacol 11:508-515.

Schoepp DD, Johnson BG, Smith ECR, McQuaid LA (1990b) Stereoselectivity and mode of inhibition of phosphoinositide-coupled excitatory amino acid receptors by 2-amino-3-phosphonopropionic acid. Mol Pharmacol 38:222-228.

Sugiyama H, Ito I, Hirono C (1987) A new type of glutamate receptor linked to inositol phospholipid metabolism. Nature 325:531-533.

Swartz KJ, Bean BP (1992a) Inhibition of calcium channels in rat CA3 pyramidal neurons by a metabotropic glutamate receptor. J Neurosci $12: 4358-4371$.

Swartz KJ, Merritt A, Bean BP, Lovinger DM (1993) Protein kinase $\mathrm{C}$ modulates glutamate receptor inhibition of $\mathrm{Ca}^{2+}$ channels and synaptic transmission. Nature 361:165-168.
Tanabe Y, Masu M, Ishii T, Shigemoto R, Nakanishi S (1992) A family of metabotropic glutamate receptors. Neuron 8:169-179.

Tanabe Y, Nomura A, Masu M, Shigemoto R, Mizuno N, Nakanishi $S$ (1993) Signal transduction, pharmacological properties, and expression patterns of two rat metabotropic glutamate receptors, mGluR3 and mGluR4. J Neurosci 13:1372-1378.

Thastrup O, Cullen PJ, Drøbak BK, Hanley MR, Dawson AP (1990) Thapsigargin, a tumor promoter, discharges intracellular $\mathrm{Ca}^{2+}$ stores by specific inhibition of the endoplasmic reticulum $\mathrm{Ca}^{2+}$-ATPase. Proc Natl Acad Sci USA 87:2466-2470.

Thayer SA, Hirning LD, Miller RJ (1988) The role of caffeine-sensitive calcium stores in the regulation of the intracellular free calcium concentration in rat sympathetic neurons in vitro. Mol Pharmacol 34: 664-673.

Trombley PQ, Westbrook GL (1992) L-AP4 inhibits calcium currents and synaptic transmission via a G-protein-coupled glutamate receptor. J Neurosci 12:2043-2050.

Tsien RW, Lipscombe D, Madison DV, Bley KR, Fox AP (1988) Multiple types of neuronal calcium channels and their selective modulation. Trends Neurosci 11:431-438.

Tsien RY (1980) New calcium indicators and buffers with high selectivity against magnesium and protons: design, synthesis, and properties of prototype structures. Biochemistry 19:2396-2404.

Yatani A, Brown AM (1989) Rapid $\beta$-adrenergic modulation of cardiac calcium channel currents by a fast $G$ protein pathway. Science 245:71-74 